\title{
Distribution of Heavy Metals in Parts of Diyala River (Basin), Iraq
}

\author{
Raad Mahmood ${ }^{1}$, Nasif Alkhafaji ${ }^{2}$ \\ College of Education for Pure Sciences, Ibn al-Haytham, University of Baghdad, Iraq
}

\begin{abstract}
Diyala River (Middle-Lower) Basin water was analyzed for (Cd, Co, Cr, Cu, $\mathrm{Ni}$, Pb and $\mathrm{Zn}$ ) in order to determine; heavy metals distribution, pollution sources, the influence of human activities and natural processes. Ten water samples were collected along Diyala River from Kalar region to the meeting point of Diyala river and Tigris river southern Baghdad city. The results had been shown that $\mathrm{Cd}, \mathrm{Co}, \mathrm{Cr}$, Ni and Pb concentrations were higher than the acceptable limits of the WHO, 2006 guideline and Iraqi guideline, 2009 for drinking water, while $\mathrm{Cu}$ and $\mathrm{Zn}$ concentrations were within acceptable limits a according to the mentioned guidelines. The most enriched metals were $\mathrm{Cr}$ and $\mathrm{Pb}$, and the occurrence of metal generally ranked in the order $\mathrm{Cr}>\mathrm{Pb}>(\mathrm{Zn}, \mathrm{Ni}, \mathrm{Co})>\mathrm{Cu}>\mathrm{Cd}$. The occurrence of these heavy metals contributed as a result of both natural processes and human resources of pollution and affected by many chemical variables in aquatic environment such as; $\mathrm{pH}$, oxidation states, oxidation and reduction effort, mobility, organic matter and hardness. These heavy metals considerable polluted elements to water. The presence of heavy metals above the acceptable limits could be toxic to aquatic organisms and harmful to human beings and that toxicity can cause several health effects.
\end{abstract}

Keywords: Diyala River, Heavy metals, water pollution, human activities

\section{Introduction}

Diyala River is one of the main water resources of Iraq and one of the most important tributaries of Tigris River in Iraq. For this reason many cities are situated on its banks, as well as, wastes fluids of agricultural and industrial activities in these cities are also concentrated directly to this river. It drains an area of about $32600 \mathrm{~km}^{2}$ lying across Iraqi-Iranian frontiers. The river basin is widely varied through the entire catchments area from semi-arid plain north of Baghdad to mountainous area of western Iran, (1). The river catchments were divided into four parts; above Derbendikhan, Upper Diyala, Middle Diyala and Lower Diyala, each of these have different characteristics and different contribution to the main river flow. From geological view point, river catchments have different geological units; above Derbendikhan the catchments lies within thrust zone and the exposed rocks are of Jurassic age, whereas the Upper and Middle Diyala lie within the folded zone in which the cretaceous strata are exposed, as well as Mukdadiya, Fatha formations and Quaternary terraces are dispersed. Lower Diyala is covered mainly by recent alluvium and lies within the unfolded zone (2). The Climatic conditions vary so much in the river catchments in which the rainy season starting from November to April, the annual amount of precipitation varies from $800 \mathrm{~mm}$ near the northern parts to $250 \mathrm{~mm}$ near southern limits of the basin. The annual evaporation rate may reach as high as $2000 \mathrm{~mm} /$ year (3). These conditions have clear effects on alteration of wet and dry years and then on the variation of river water quality. However, the catchments area of Diyala river are lies within highly cultivated regions and have many canals and drainage channels, which contributing and affects river hydrochemistry. The Diyala River basin is one of these basins, which cover the important parts of Iraq and its impact in the quality of the waters of the Tigris, which meets the latter south of Baghdad (4,5). Diyala River basin is located between latitudes $\left(13^{\circ} 33-50^{\circ} 35\right)$ and between the longitudes $\left(30^{\circ} 44-50^{\circ} 47\right)$ and passes the river in Diyala province northeast of Baghdad, Figure (1). 


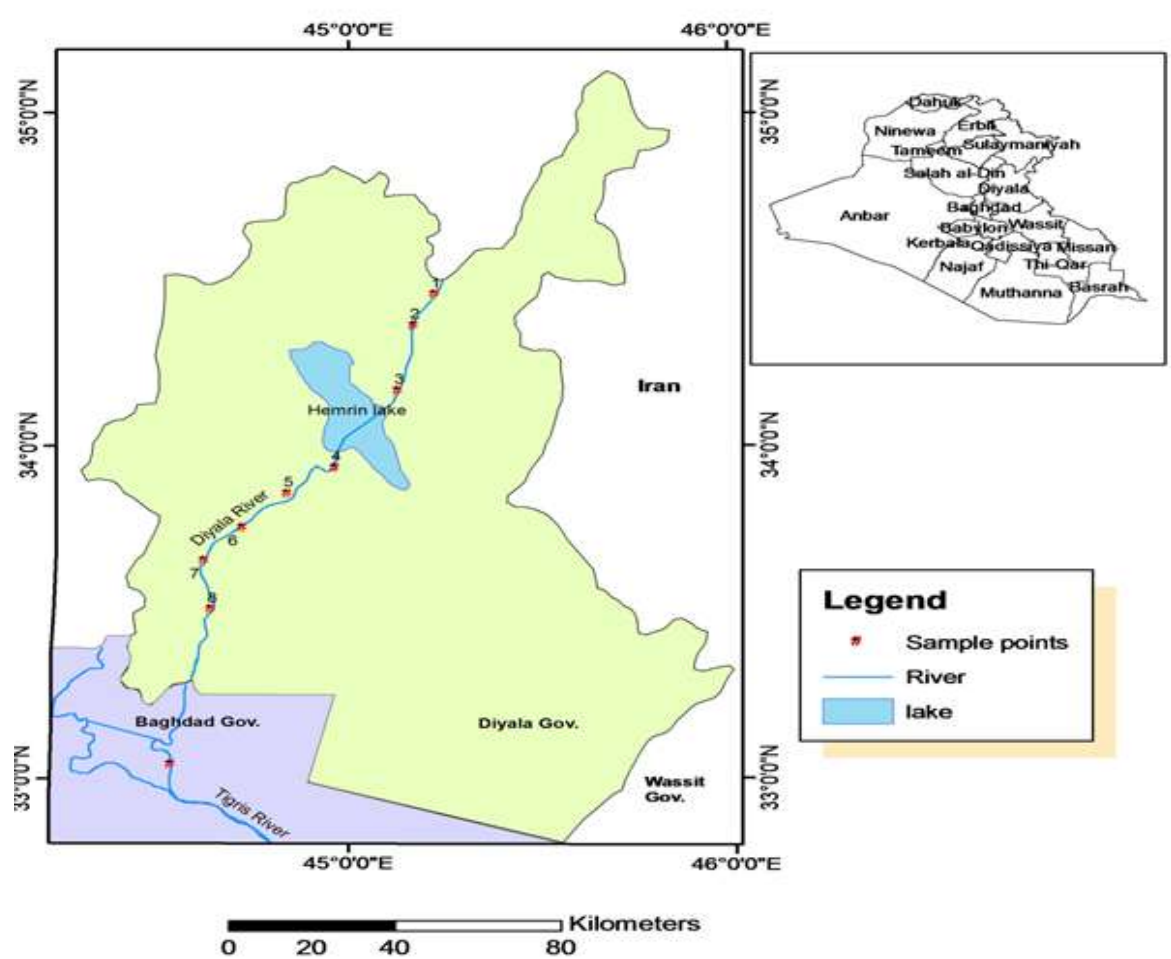

Figure 1: Study area and sampling stations, modified from (6)

The Aim of the study:

The main objective of the study is to determine distribution of heavy metals of Diyala River and the amount of pollution that exposed by these metals.

\section{Methodology}

For this study numerous stations had been sampled. Ten water samples were collected from the study area during September 2010 and April 2011. The samples covered the study area from Kalar to the mouth of Diyala in Tigris river (The locations and distribution of these samples are showing in Fig.1). For the analysis of heavy metals, samples were collected in polyethylene bottles, after wash bottle with Water River twice, and then take the sample at a depth of 20 $\mathrm{cm}$ and close tightly; $\mathrm{pH}$ was measured for each station. One milliliter of nitric acid was added locally to the samples and then transported to analysis by atomic absorption spectroscopy in the laboratory of college of sciences.

\section{Results and Discussion}

The most important heavy elements for the water are: $(\mathrm{Zn}$ and $\mathrm{Cu}$ and $\mathrm{Pb}, \mathrm{Cd}$ and $\mathrm{Hg}, \mathrm{Ni}$ and $\mathrm{Cr}$ ) and some of these elements, such as ( $\mathrm{Zn}$ and $\mathrm{Cu}$ and $\mathrm{Ni}$ and $\mathrm{Cr}$ ) are necessary as trace components, but become toxic at high concentrations, depending on the dose of the object organism the other elements such as lead, cadmium does not have the functions of life, but is only toxic elements (7). And inorganic contaminants are the largest industrial polluter of water heavy elements (8). Path of heavy metals in aquatic systems depends on the partition between the solid and liquid phase, operations adsorption, associated sedimentation process, and form complexes, the same operations are affected by oxidation-redox Eh, $\mathrm{pH}$ and water ionic force (9). It is difficult to limit the health effects of all of the heavy metals because of the large number of metals, and the fact that each metal causes a number of different problems, and that the presence of heavy metals in the water lies between the farming land depends on the biological and non-biological variables like characteristics of the drainage basin and permeability of soils, the amount of falling rain, the proportion of land is cultivated, planted and the amount and type of fertilizer used (10).

Mean $\mathrm{pH}$ values in the study area stations ranged from 7.1 7.8 with average of 7.36 was within acceptable limits according to the WHO, 2006 guideline(11) and Iraqi guideline, 2009 (12) for drinking water.

Diyala river water was analyzed for $\mathrm{Cd}, \mathrm{Co}, \mathrm{Cr}, \mathrm{Cu}, \mathrm{Ni}, \mathrm{Pb}$ and $\mathrm{Zn}$, each metal as described below:

\section{1-Cadmium (Cd):}

Mean Cadmium concentrations in the studied samples ranged from 0- $0.1 \mathrm{ppm}$ with $0.05 \mathrm{ppm}$ in average, and this average was more than Iraqi limits 2009(12) and WHO, 2006 for drinking water(11),Figure (2), Table( 1). The highest $\mathrm{Cd}$ concentration was in Al-Rustumia station, where this station is a treatment station for sewage waste water that thaws polluted water to Diyala River.

Cadmium occur in nature in (zinc, copper, lead) ores, coal, types of fossil fuels and shale, and is emitted during the events volcanic, and these sediments can be a source of pollution of surface water and groundwater, especially when they are in contact with them, as well as most industries output cadmium waste into rivers (13). Also human activities add an estimated about (3-10) times of cadmium than add by natural resources to atmosphere (14). Where $\mathrm{Cd}$ enters in the manufacture of steel and plastic industries, and cadmium compounds are widely used in batteries, and pollution caused by the higher cadmium fertilizers (11). The geochemical behavior of cadmium similar to zinc in terms of 


\section{International Journal of Science and Research (IJSR) \\ ISSN (Online): 2319-7064}

Index Copernicus Value (2016): 79.57 | Impact Factor (2015): 6.391

its tendency to be associated with sulfur, the two elements are subject to many geochemical processes together, and both elements are found on the water in the oxidation state (+2) (8). Dissolved cadmium in the water accumulates more easily in the sediment than in biological matters, Cadmium has high transition and a relatively high abundance of life, it is non-essential for the life of plants and animals (8), and easy accumulation in microorganisms and mollusks where it is easier adsorbed if it exists as free ion $\left(\mathrm{Cd}^{+2}\right)$, and its toxicity varies as species varies. Cadmium adverse effects in humans included: nausea, vomiting, diarrhea, muscle cramps, salivation, sensory disturbances, renal failure, and liver and kidney damage in the long run (13).

\section{2- Cobalt (Co)}

Mean Cobalt concentrations in study area ranged from 0. $0.19 \mathrm{ppm}$ with $0.104 \mathrm{ppm}$ in average (Figure (2), Table (1). This average was higher than WHO, 2006 guideline for drinking water, the highest Co concentration was in AlRustumia station and before Diyala mouth in Tigris river, then the values decreased after the meeting of the two rivers because of dilution happened after meeting.

Cobalt is a high transition element deposited with limonite and hydrous manganese dioxide as well as with nickel in strongly geochemical conformance (15). It is one of the widespread and relatively low abundance in the earth's crust (16). Cobalt occurs in six cases of valence, but in aquatic environment $\left(\mathrm{Co}^{2+}\right.$ and $\left.\mathrm{Co}^{+3}\right)$ are available (17). Cobalt enters the environment from natural and anthropogenic sources include volcanic projectiles and sea spray, forest fires, mining activities, operations and rain storms, is also a contributor to agricultural activities in the launch of the president of cobalt to the environment. The cobalt is necessary micronutrients for the various organisms, but be toxic when exceeding its focus on the limits, and in humans, exposure to high concentration of cobalt causes diarrhea and low blood pressure and body temperature as well as symptoms of other health and may lead to death (18). And to protect organisms in the fresh water from the acute toxic effect of cobalt should not 2.4 exceed the upper limit of cobalt concentration on the rate of $(0.0001 \mathrm{ppm})$ and the toxic effect of chronic for (0.0004 ppm) (17).

\section{3-Chromium (Cr)}

Mean Chromium concentrations ranged from 0-2.55 ppm with $0.88 \mathrm{ppm}$ in average, Figure (2), Table (1). This average was higher than Iraqi limits 2001and WHO, 2006 for drinking water, the highest concentration was in AlRustumia station and before Diyala mouth in Tigris river, then the values decreased after the meeting of the two rivers because of dilution happened after the meeting.

Chemical properties and toxicity of chromium varies depending on the valence state (17). There are cases of chromium oxidation of the $(-2$ to +6$)$, but only two oxidation states $\left(\mathrm{Cr}^{+3}, \mathrm{Cr}^{+6}\right)$ are stable under the most natural aquatic environments (19). The geochemical behavior and toxicity to lives (Biological Toxicity) of $\mathrm{Cr}$ in both cases varies since the $(\mathrm{Cr} \mathrm{VI})$ tends to become negative dissolved ionic forms or types of natural insoluble, can be high mobility and is acutely toxic to the contrary, (Cr III) tends to precipitate in a positive dissolved ionic species and is immobile under basic conditions and weak acidic conditions and relatively nontoxic (20). (21) illustrated that the concentration of dissolved chromium depends strongly on the $\mathrm{pH}$ and oxidation and reduction effort, where the (Cr III) stable under the reductionism and medium oxidation conditions, while hexavalent chromium is stable under the strong oxidation conditions and that the components of hexavalent chromium used in an industrial operations as oxidation agent and in the environment near the disposal sites. Where chromium enters to the environment from sewage waste water, printing dyes, chemical fertilizers and tanning. The presence of chromium concentrations above the limits could be toxic to aquatic organisms and harmful to human beings and that the toxicity of chromium to be affected by water hardness (22). High levels of chromium can cause several health effects on the eyes, abdominal pain, severe bleeding, vomiting, and longterm exposure can cause cancer (18).

\section{4- Copper (Cu)}

Mean Copper concentrations ranged between $0-0.197 \mathrm{ppm}$ with $0.069 \mathrm{ppm}$ in average, this average was less than Iraqi, 2009 and WHO, 2006 guideline for drinking water Figure (2), Table(1). $\mathrm{Cu}$ concentrations varied among stations, the highest value was in Kalar station, due to human activities.

Copper element exists naturally in all water systems at low levels, and is one of the essential micronutrients for plants and animals, no copper ion in the water in bivalence, in which case the most stable in aqueous solutions (16). Copper ion characterized by low concentration in natural waters because of synchronizes deposited with oxides minerals and adsorption on clay minerals. In acidic oxidized environment, copper has high mobility (23).The presence of copper at high concentrations in the water will be toxic to aquatic organisms with the ionic form of this element, which becomes more toxic and hardness and the other chemical variables can limit exposure to the sharp copper impact, in addition to the impact of $\mathrm{pH}$ and organic matter on the acute copper impact (24). The range between deficiency and toxicity of copper in heterogeneous organisms are as large as the mechanism of copper toxicity is complex in biology (18). Copper is one of the metals that are easily removed from solution by adsorption on particulates or by forming complexes with organic molecules (25).

\section{5- Nickel (Ni):}

Mean Nickel concentrations rangesd between $0-0.265 \mathrm{ppm}$ with $0.17 \mathrm{ppm}$ in average, this average was more than Iraqi, 2009 and WHO,2006 guideline for drinking water Figure (2), Table( 1). The highest Ni value was in Al-Rustumia, and then the values decreased before the mouth of Diyala in Tigris River and then slightly increased after meeting of the two rivers.

Nickel is present in natural waters mainly in Hexahydrate $\mathrm{Ni}\left(\mathrm{H}_{2} \mathrm{O}\right)_{6}^{+2}$ form, and a nickel complexes strong dissolved with $\left(\mathrm{OH}^{-}, \mathrm{SO}_{4}{ }^{-2}, \mathrm{HCO}_{3}{ }^{-}\right)$and these species a secondary link with hydrated nickel in $(\mathrm{Ni}+2)$ in surface water and groundwater with a $\mathrm{pH}$ less than $(9>\mathrm{PH})(11)$. (16) referred that the case of $\left(\mathrm{Ni}^{+2}\right)$ is only important in aqueous solutions and the fact that they the case of $\left(\mathrm{Ni}^{+2}\right)$ is high stabilizing, so the Redox Reactions is non common in aqueous solutions of nickel. Ni considered toxic metal to water environment

\section{Volume 6 Issue 12, December 2017}




\section{International Journal of Science and Research (IJSR) \\ ISSN (Online): 2319-7064}

Index Copernicus Value (2016): 79.57 | Impact Factor (2015): 6.391

and the increase of $\mathrm{Ni}$ content come due to industrial activities; steel, alloy, sanitation (5).

\section{6- Lead (Pb)}

Mean Lead concentrations ranged from $0.05-0.77 \mathrm{ppm}$ with $0.24 \mathrm{ppm}$ in average, this average was more than Iraqi, 2009 and WHO, 2006 guideline for drinking water (Figure (2), Table( 1$)$, the $\mathrm{Pb}$ content increased gradually after AlRustumia and before mouth of Diyala in Tigris river and after meeting of the two rivers.

Lead one of the most heavy metals common, it is one of the nutrients unnecessary (18). Inorganic lead enters to the environment as a result of both natural processes and human resources such as operations mining and smelting, cement and use of fuel, which is the main source of lead in the atmosphere and ground, which enters largely in the end to aquatic systems (8). It also lead enters in many other industries such as manufacturing of pipes and plates, batteries, paints, fertilizers and pesticides which contribute to pollution of the environment (25). Lead occurs in state of $\left(\mathrm{Pb}{ }^{+2}, \mathrm{~Pb}^{+3}\right)(18)$. The $\mathrm{Pb}^{+2}$ ions are the most prevalent in the aquatic environment (8). Because of the lack of lead solubility compounds and the lack mobility and its absorption on the outer surface of organic and inorganic materials that caused lack of concentration in surface water and groundwater (23). Of the most important factors affecting the toxicity of lead to aquatic organisms, its concentration as a free ion and the amount of lead depends on a limited number of factors including $\mathrm{pH}$ and water hardness (26). The organic lead more abundant and toxic than inorganic lead (25). For easy absorption by the tissues of the organism, the accumulation of lead in objects varies depending on the nature of the components of lead and environmental load of it (18). And the important health effects of lead on humans, including the appearance of pain in the digestive system and liver damage, kidney and appears to lead poisoning of the leading causes of mental retardation in children (18).

\section{7- Zinc}

Mean Zinc concentrations ranged from 0- $0.40 \mathrm{ppm}$ with $0.104 \mathrm{ppm}$ in average (Table 1), this average was less than Iraqi, 2009 and WHO,2006 guideline for drinking water Figure (2), Table(1). The highest $\mathrm{Zn}$ content was before the meeting of the two rivers.
Transportation and distribution of zinc in water, sediment and soil depends on the forms which zinc occur, characteristics of the environment, and that the solubility of zinc is determined by the $\mathrm{pH}$, When acidic $\mathrm{pH}$ values there is zinc in the ionic aqueous phase (22). When the $\mathrm{pH}$ is greater than 7 zinc is deposited, so its presence depends on the low basic and accompanied with sulphides, where $\mathrm{Zn}$ solubility increases vulnerability in the oxidation acidic environment, and its solubility reduces with presence of sulfur in the reduction environment when forming few soluble sulfur compounds (18). The toxicity of zinc and copper mobility associated with low $\mathrm{pH}$ and hardness, and basic and dissolved organic carbon. Zinc enters the to the aquatic environment of the activities of natural and industrial, and more zinc in the aquatic environment is transmitted to the bottom and generally small amounts of it remain dissolved or adsorbed on the suspended particulates , its occur in the water status of $\left(\mathrm{Zn}^{+2}\right)$,one of the important elements for the growth of humans and animals, especially in the early stages of growth and development, although the amount needed to very few, lack of zinc causes a deficiency in the bones and joints and affects the skin and fertility (27). And increase the concentration of zinc in humans at the expense of iron, copper, and cause nausea, vomiting, fever, headache, fatigue, abdominal pain (28). The high concentration of zinc in water, especially for the permissible limits is toxic to a number of types of algae and fish as the high concentrations of zinc with a strong influence, especially on some aquatic such as mullasca, and is often zinc and copper are the heavy elements responsible for toxicity, especially for fish, especially in times of storms rain (28).

The most enriched metals heavy metals in the studied samples of Diyala river were $\mathrm{Cr}$ and $\mathrm{Pb}$, and the occurrence of metal generally ranked in the order $\mathrm{Cr}>\mathrm{Pb}>(\mathrm{Zn}, \mathrm{Ni}, \mathrm{Co}$ )$>\mathrm{Cu}>\mathrm{Cd}$.

In comparison data of heavy metals with previous work issued in Al-Adili, 1992; $\mathrm{Cd}, \mathrm{Pb}$ and $\mathrm{Zn}$ are clearly increased. These heavy metals considerable polluted elements to water and its occurrence contributed as a result of industrial wastes and these metals moves through water in adsorbed ions form on the suspended sediments particulates forming metal covers, or it forms complexes by union (incorporate) with inorganic negative ions after dissolved in water (5).

Table 1: Mean Concentration of heavy metals in Diyala River (ppm) from September 2010 to April 2011

\begin{tabular}{|c|c|c|c|c|c|c|c|c|c|}
\hline No & Location & $\mathrm{pH}$ & $\mathrm{Cd}$ & $\mathrm{Co}$ & $\mathrm{Cr}$ & $\mathrm{Cu}$ & $\mathrm{Ni}$ & $\mathrm{Pb}$ & $\mathrm{Zn}$ \\
\hline 1 & Kalar & 7.2 & 0 & 0.131 & 1.78 & 0.197 & 0.182 & 0.052 & 0.035 \\
\hline 2 & Kalar & 7.2 & 0.08 & 0.081 & 0.12 & 0.087 & 0 & 0.437 & 0 \\
\hline 3 & Before Al- Rustumia Rustumia & 7.1 & 0.032 & 0.045 & 0 & 0.096 & 0.098 & 0.136 & 0.102 \\
\hline 4 & Al-Rustumia Station & 7.2 & 0.108 & 0.192 & 2.555 & 0.078 & 0.265 & 0.051 & 0.176 \\
\hline 5 & After Al-Rustumia & 7.8 & 0 & 0.187 & 1.803 & 0.09 & 0.112 & 0.208 & 0.133 \\
\hline 6 & Before mouth & 7.4 & 0.02 & 0.066 & 0.17 & 0 & 0.066 & 0.191 & 0.062 \\
\hline 7 & Before mouth & 7.4 & 0.094 & 0.183 & 2.01 & 0.08 & 0.070 & 0.778 & 0.408 \\
\hline 8 & Before mouth & 7.5 & 0.061 & 0.168 & 0 & 0.07 & 0.108 & 0.208 & 0.093 \\
\hline 9 & Meeting Diyala \& Tigris & 7.5 & 0.067 & 0.05 & 0.413 & 0.02 & 0.160 & 0.13 & 0.086 \\
\hline 10 & Meeting Diyala \& Tigris & 7.3 & 0.059 & 0 & 0.01 & 0 & 0.070 & 0.286 & 0.069 \\
\hline & Range & $7.1-.7 .8$ & $0-0.1$ & $0-0.187$ & $0-2.55$ & $0-0.197$ & $0-0.256$ & $0,05-0.77$ & $0-0.40$ \\
\hline & Average & 7.36 & 0.05 & 0.1044 & $0 . .94$ & 0.104 & 0.176 & 0.245 & 0.104 \\
\hline & Iraqi limits,2009 & $6.5-8.5$ & 0.00 & --- & 0.05 & 1 & 0.02 & 0.01 & 3 \\
\hline & WHO,2006 & $6.5-9.5$ & 0.00 & 0.05 & $<1 \mu \mathrm{g} / 1$ & 2 & 0.07 & 0.01 & $3-1.1$ \\
\hline
\end{tabular}

Volume 6 Issue 12, December 2017 


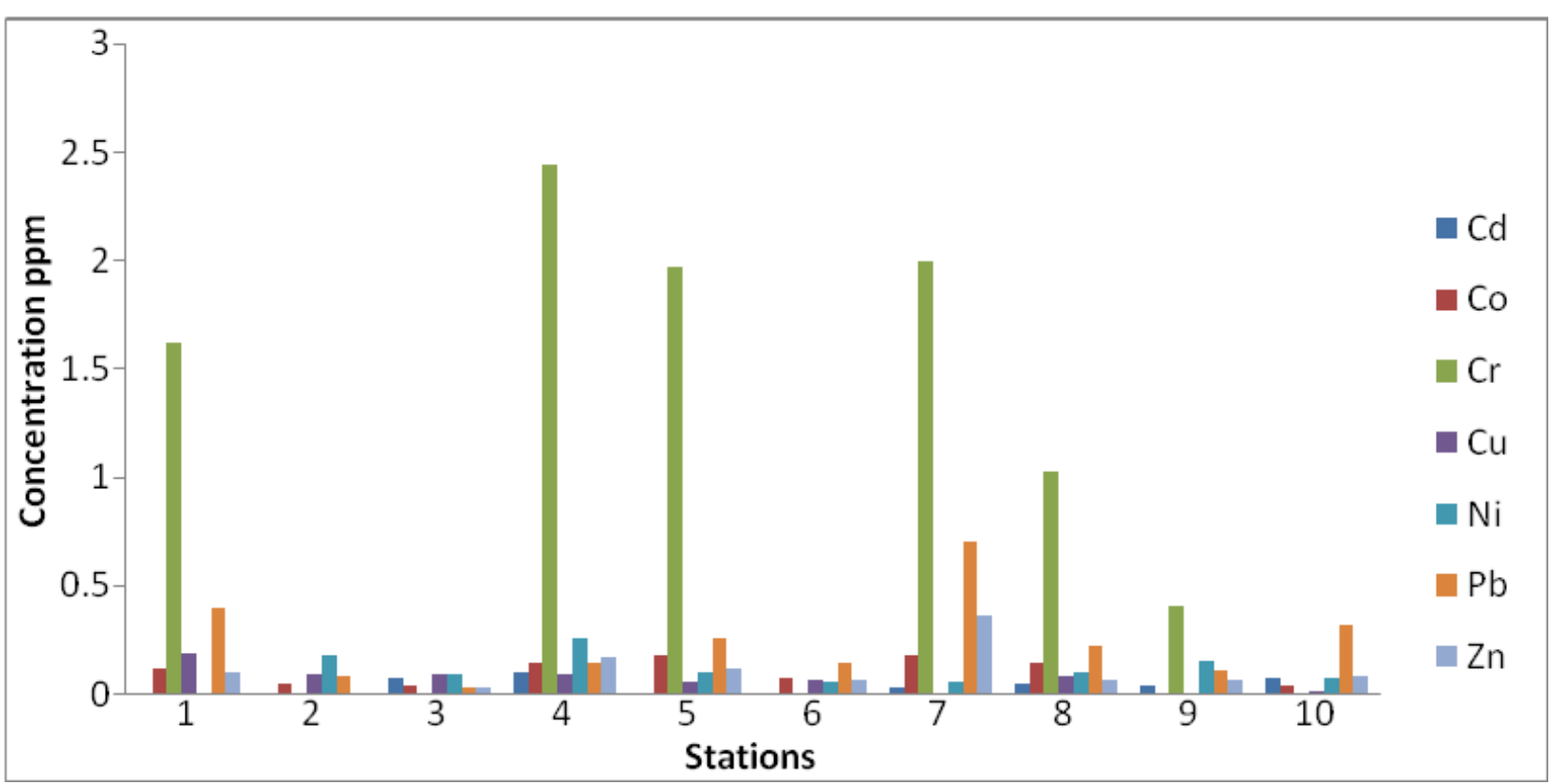

Figure 2: Distribution of heavy metals in study area stations. Between september2010 to April 2011

\section{Conclusion}

1) Heavy metals $(\mathrm{Cd}, \mathrm{Co}, \mathrm{Cr}, \mathrm{Ni}$ and $\mathrm{Pb})$ in the studied samples of Diyala river found to be higher than the acceptable limits of Iraqi, 2009 and WHO,2006 for drinking water; whereas $\mathrm{Cu}$ and $\mathrm{Zn}$ appeared to have values less than the acceptable limits of Iraqi, 2009 and WHO, 2006 for drinking water.

2) The most enriched metals were $\mathrm{Cr}$ and $\mathrm{Pb}$, and the occurrence of metal generally ranked in the order $\mathrm{Cr}>$ $\mathrm{Pb}>(\mathrm{Zn}, \mathrm{Ni}, \mathrm{Co})>\mathrm{Cu}>\mathrm{Cd}$.

3) The occurrence of these heavy metals contributed as a result of natural sources of pollution of surface water and groundwater (events volcanic, fossil fuels) and affected by many agents in aquatic environment such as; $\mathrm{pH}$, oxidation states, oxidation and reduction effort, mobility, hardness, organic matter and the other chemical variables.

4) These heavy metals considerable polluted elements to water and enter to the environment as a result of both natural processes and human resources such as; operations mining and smelting, cement and use of fuel, manufacture of steel and plastic industries, manufacturing of pipes and plates, batteries, paints, fertilizers and pesticides, sewage waste water, printing dyes, and tanning.

5) The presence of heavy metals concentrations above the limits could be toxic to aquatic organisms and harmful to human beings and that the toxicity of heavy metals can cause several health effects.

6) Toxicity of heavy metals to organisms varies as species varies.

\section{References}

[1] Al- Ansari, N.and Al-Jabbari, M.1987: Hemrin reservoir, geological and hydrological investigation, J.of Water Res., Special Publ. No. 2, sector 2.
[2] Al- Ansari, N., Al-Jabbari, M. and Al-Shakiri,A. 1987a: Reservoir, geological and hydrological investigation, J. of Water., Special Publ. No. 2, sector 3.

[3] Al-Jiboury, T.H.1991:Hydrology and geomorphology of Diyala River, Unpub. Ph.D. thesis, Univ. of Baghdad,238p.

[4] Al-Timemi, O.S. 2007: Assessment of water resources in Diyala River basin- middle part. Unpub. Ph.D. thesis, Univ. of Baghdad, College of Science, 165p.

[5] Al-Adili, A.S. 1992: The impact of human activities on water quality of Diyala River, Unpub. MS.C. thesis, Univ. of Baghdad, College of Science, 108p.

[6] http://www.iauiraq.org/gp/inc/0/default.asp.

[7] Duruibe, J. O., Ogwuegbu, M. O. C. and Egwurugwu, J. N., 2007. Heavy metal pollution and human biotoxic effects. Journal of Physical Sciences Vol. 2 (5), pp 112 118. Available online at http://www.academicjournals.org/IJPS.

[8] Manahan, S. E., 2001. Fundamentals of Environmental Chemistry Boca Raton: CRC Press LLC, 993p.

[9] ATSDR (U.S. Dep., of health and health services), 2005. Toxicological profile for nickel. U.S. Dep., of health and health services, Public Health Service. Atlanta, Georgia 30333, 345p. internet: http://www.atsdr.cdc.gov

[10] Karlik, B. Szpakowska, B., 2001. Labile organic matter and heavy metals in waters of agricultural landscape. Polish Journal of Environmental Studies Vol. 10, No. 2, pp 85-88

[11]WHO, 2006: Guideline for Quality, $3^{\text {rd }}$ ed. Vol. 1: Recommendations, Geneva:515pp.

[12] Ministry of Planning and Development Cooperation, Central Agency for Standardization and Quality Control, Standard No, (417), 2009,Drinking water,p.9.

[13] WQA (Water Quality Association), 2006. RO Water Chemistry. Applied Water Solutions, Inc. www.idswater.com/Common/Paper/Paper_212/RO Water Chemistry.

[14] Irwan, R. J., 1997a. Environmental contaminants encyclopedia cadmium entry. National Park service with assistance from Colorado State University. Water

\title{
Volume 6 Issue 12, December 2017
}

\author{
www.ijsr.net
}




\section{International Journal of Science and Research (IJSR) \\ ISSN (Online): 2319-7064}

Index Copernicus Value (2016): 79.57 | Impact Factor (2015): 6.391

resources divisions, water operation branch, 1201

Oakridge Drive, Suite 250, Fort Collins, Colorado 80525, 88p.

[15] Rankama K. and Sahama, Th., G., 1950. Geochemistry. University of Chicago press, 911p.

[16] Nicholls, D., 1993. Complexes and First Transition elements. $6^{\text {th }}$ ed. Antony Rowe, chippenham, Wiltshire Great Britain. 215p.

[17] Nagpal, N. K., 2004. Technical report, water quality guidelines for cobalt [electronic resource]. Water Protection Section, Ministry of Water, Land and Air Protection, Golder Associates, British Columbia. ISBN 0-7726-5229-5, 59p.

[18] Venugopal, B. and Luckey, 1978. Metal toxicity in Mammals.2, Chemical toxicity of metals and metalloids. Plenum press, New York and London, 409p.

[19] Batchelor, B., Schlautman, M., Hwang, I. and Wang, R., 1998. A Report on Kinetics of Chromium (VI) Reduction by Ferrous Iron. Amarillo National Resource Center for Plutonium. Dep. of Civil Engineering Texas A\&M University. Texas 77843-3136. PP15

[20] Krupka, K. M., Kaplan, D. I., Whelan, G., Serne, R. J. and Mattigod, V. S., 1999. Understanding variation in partition coefficient, Kd, value volume II: Review of Geochemistry and Available Kd Values for Cadmium, Cesium, Chromium, Lead, Plutonium, Radon, Strontium, Thorium, Tritium (3H), and Uranium, U.S. Environmental Protection Agency, Washington, DC 20460, 334p.

[21] Deutsch, W. J., Krupka, K. M., Cantrell, K. J., Brown, C. F., Lindberg, M., Schaef, H. T., Heald, S. M., Arey, W., Kukkadapu, K., 2005. Advances in geochemical testing of key contaminants in residual Hanford tank waste. Office of Scientific and Technical Information, Pacific Northwest National Laboratory Richland, Washington 99352. PNNL-15372, 135p.

[22]WHO, 2005. Bentonite, kaolin, and selected clay minerals. (Environmental health criteria ; 231), Geneva, Switzerland, ISBN 924157231 0, 175p.

[23] Hem, J. D., 1985. Study and interpretation of the chemical characteristics of natural water. USGS Water Supply, Washington, Paper, 2254, 264p.

[24] Grosell, M., Nielsen, C. and Bianchinib, A., 2002. Sodium turnover rate determines sensitivity to acute copper and silver exposure in freshwater animals. Biochemistry and Physiology Part C 133, pp 287-303

[25] Clark, R. B., 1998. Marine pollution. $4^{\text {th }}$ ed., Bath press. Bath, 161p. ISBN 019850069.

[26] NHMRC, 2004. Australian Drinking Water Guidelines. National Water Quality Management Strategy, 615p. web address: http://www.nhmrc.gov.au.

[27] Keller, W. D., 1970. Sedimentary petrology an introduction, back well scientific pub., Oxford, 252p.

[28] Irwan, R. J., 1997b. Environmental contaminants encyclopedia Zinc entry. National Park service with assistance from Colorado State University. Water resources divisions, water operation branch, 1201 Oakridge Drive, Suite 250, Fort Collins, Colorado 80525, 88p.

Volume 6 Issue 12, December 2017 www.ijsr.net 